\title{
Addressing the Blurred Edges of Turkey's Diaspora and Religious Policy: Diyanet Women Preachers sent to Europe
}

\section{Chiara Maritato}

\section{(2) OpenEdition Journals}

Electronic version

URL: http://journals.openedition.org/ejts/6020

DOI: $10.4000 /$ ejts.6020

ISSN: $1773-0546$

Publisher

EJTS

Electronic reference

Chiara Maritato, «Addressing the Blurred Edges of Turkey's Diaspora and Religious Policy: Diyanet Women Preachers sent to Europe », European Journal of Turkish Studies [Online], 27| 2018, Online since 23 December 2018, connection on 16 February 2020. URL : http://journals.openedition.org/ejts/ 6020 ; DOI : 10.4000/ejts.6020

This text was automatically generated on 16 February 2020.

(c) Some rights reserved / Creative Commons license 


\title{
Addressing the Blurred Edges of Turkey's Diaspora and Religious Policy: Diyanet Women Preachers sent to Europe
}

\author{
Chiara Maritato
}

I would like to thank the Stockholm Lerici Foundation grant and the Austrian OeAD fellowship which allowed me to conduct fieldwork in Sweden and Austria in 2017. The article has been conceived, drafted and finalised between the Stockholm University Institute for Turkish Studies (SUITS), the Centre for Southeast European Studies (CSEES) of the University of Graz and the Department of Cultures, Politics and Society (DCPS) of the University of Turin. For their invaluable feedbacks and support I am grateful to Jenny White, Paul Levin, Kerem Öktem, Rosita Di Peri and Luca Ozzano.

\section{Introduction}

1 Since the early 2000s, women have been included in the quota of religious officers [din görevlisi] the Turkish Presidency of Religious Affairs [Diyanet Isşleri Başkanlığı, hereinafter Diyanet] regularly sends to Turkish Muslim communities abroad. Tasked with organising sermons, Qur'an readings and preaching sessions in Diyanet mosques, they provide religious knowledge and moral support to women and families.

2 The decision to send female Diyanet officers - particularly women preachers [vaize, pl. vaizeler] - abroad can be linked to two concomitant processes that started in the early 2000s: on the one hand, the religious bureaucracy represented by the Diyanet has redefined its role and agency (Lord 2018) in Turkish society. Beginning in 2003, under Ali Bardakoğlu's presidency, the Diyanet increased the number of women employed as Qur'an teachers, preachers, religious experts and vice-muftis, and launched a campaign to invite women to mosques (Maritato 2015, 2017). Female personnel increased both in number and competences, rising from 2,696 in 2004 to 17,738 in 2017 (Diyanet İşleri 
Başkanlığı 2018), a process culminating with the appointment of a woman, Huriye Mart1, to the vice-Presidency ${ }^{1}$ of the institution. The feminisation of the institution occurred parallel with a redefinition of the religious officers [din görevlisi] whose role and competences have expanded. In Turkey and in its branches in Europe, religious officers have found fertile ground to claim a new role beyond the mosques - providing moral support in hospitals, houses, orphanages, shelters and prisons. They also serve as a trustee of professionals whose high competences in religious affairs could enlighten people via a set of low-threshold services such as the family guidance bureaus (Yazıc1 2012; Kocamaner 2017) located in local mufti offices.

3 On the other hand, with the rise to power of the Justice and Development Party [Adalet ve Kalkınma Partisi, hereinafter AKP], the Diyanet has risen to prominence as one of the largest state agencies whose budget and employees have skyrocketed (Öztürk 2016). Although since 1971 the Diyanet imams and preachers have been sent to 'guest worker' communities in Europe during religious feasts or the Ramadan month (Yurdakul \& Yükleyen 2009), the Diyanet's grip on international affairs stemmed from the aftermath of the 1980s military coup. The Diyanet's current international mission has been investigated by a vast scholarship (Akgönül 2005; Allievi \& Nielsen 2003; Avci 2005; Sunier \& Landman 2014; Sunier et al. 2011) who examined how the institution has risen to prominence as a foreign policy actor (Öktem 2012; Yurdakul \& Yükleyen 2009; Yükleyen 2011). The decision to send Diyanet female religious officers to the Turkish Muslim communities in Europe should thus be assessed within the frame of a twofold process: the feminisation of the institution and a redefinition of the Diyanet's international mission as a larger reconfiguration of Turkey's diaspora policies. How does the 'export' of Diyanet female religious officers fit into Diyanet's grip for international affairs? What is women's contribution in this respect? And how do the activities of Diyanet women preachers in Europe reflect Turkey's current diaspora policies?

4 According to the Turkish Ministry of Foreign Affairs (MFA n.d.), about 1,400 religious officers are currently employed outside Turkey. However, despite the flourishing of scholarship addressing Diyanet's wide-ranging international mission, the activities of Turkish religious officers abroad remain understudied with only a few exceptions focusing on the imams (Bruce 2012; Çitak 2010; Öztürk \& Sözeri 2018). The work of Zekiye Demir (2010), who conducted a quantitative research on Turkish women's daily life in Germany, is one exception. Her study, published by Diyanet, describes religious officers' engagement in spreading what Islam says about problems within the family and about woman's role within the family (Demir 2010: 36-38). It particularly emphasises that religious services for women have increased since the early 2000s and that, starting from 2007, female personnel sent abroad have also been trained on topics like "the Profile of Expatriate Women and Families". Moreover, the scarcity of scholarly work is connected to a lack of systematic data on the number of female religious officers employed outside Turkey. In 2009, the official report of Diyanet's annual activities stated that 52 Diyanet female officers operated in 15 countries (Diyanet Iş̧leri Başkanlığ1 2011); more recently, Diyanet reports only mention the number of personnel employed as male religious attachés and counsellors, 53 in 2016 and 43 in 2017, without specifically mentioning the countries or the exact number of male and female din görevlisi sent abroad. The 2017 report, for instance, states that a total of 366 religious 
officers have been sent to Europe, without mentioning the exact number of female religious officers or the exact data sorted by countries (Diyanet İşleri Başkanlığı 2018).

Drawing from the methodology of political ethnography (Auyero 2006; Schatz 2013; Wedel et al. 2005; Yanow 1996) and ethnography of policy (Dubois 2009; Shore \& Wright 1997), this study analyses Diyanet policies toward women and families living in Europe through direct observation of female religious officers' activities. The work particularly provides insights from the Diyanet foundations in Austria ${ }^{2}$ (Vienna) and Sweden ${ }^{3}$ (Stockholm). Currently, 100,000 Swedes have Turkish background (Levin \& Baser 2017); in Austria, the number was 271,000 in $2016^{4}$. In this regard, my previous fieldwork in Turkey to investigate the Diyanet policies towards women and the family provided me with a list of contacts and references that allowed me to approach Diyanet personnel in both Sweden and Austria. All the preachers ${ }^{5}$ I contacted allowed me not only to attend their sermons and Qur'an seminars in mosques; they also invited me into their homes, introducing me to their relatives. Gaining trust was instrumental in observing the multifaceted activities that the women preachers are assigned with besides the sessions in mosques.

6 The observations of the daily activities organised by Diyanet female religious officers in Austria and Sweden are combined with a careful examination of Diyanet directives, circulars and reports published by the Diyanet International Relations Department [Dış İlişkiler Genel Müdürlügü]. The sources consist of official publications and interviews with the personnel employed in Diyanet offices, members of the female sections [kadin kollarl] and religious officers (mainly preachers and Qur'an teachers). This paper emphasises that female religious officers' activities abroad should be included in a multifaceted reconfiguration of: i) the Diyanet long-lasting international mission; ii) the role women play in the diffusion of religious knowledge and morality; iii) the boundaries between Turkey's religious and diaspora policies.

\section{The Diyanet as an International Actor. Where Do Women Stand in It?}

7 Since its foundation in 1924, the Diyanet has been strategically employed as one of the most well-oiled transmission belts through which state ideology (Aydın 2014; Ünver 2013) is propagated both in Turkey and abroad. In this respect, Zana Çitak confirms that the Diyanet acted as "both a domestic and an external policy instrument of the Turkish state in the context of national identity and the evolution of the role of religion in the Turkish polity" (Çitak 2017: 11). The Turkish state could resort to a channel of religious bureaucrats through which it propagated ideology and implemented policies aimed at preserving an ethnic and religious identity. For its malleability, the Diyanet managed to reconfigure its agency according to the evolution of religious policies and politics. In the 1930s and 1940s, the assertive secularism characterising the early republican separation between religion and the state, better defined as laicism [laiklik], aimed to bureaucratise and control religion (Gözaydın 2008; Davison 2003). However, Turkish laicism consistently evolved with the move to a multiparty system in the 1950 s. The mission of the Diyanet expanded to include the diffusion of morality throughout society (Gözaydın 2014), religion became more prominent as part of public affairs, and state policies regarding religion evolved. On this matter it is important to mention the opening of the religious vocational high schools [imam hatip] whose number increased 
particularly in the 1960s and 1970s (Ozgur 2012). In the 1970s, the elaboration of the Turkish-Islamic synthesis as a doctrine and a state ideology combining nationalism with Islam marked the Cold War order. Conceived against the rise of communist ideologies, the Turkish-Islamic synthesis de facto contributed to the maintaining of the status quo particularly in the aftermath of the 1980s military coup (Eligür 2010: 93-102). At that time, the introduction of compulsory religion classes in state schools, the rising number of Diyanet Qur'an courses and imam hatip schools combined with a redefinition of the Diyanet's role: From an agency embodying a domesticated religion to a ruling instrument in the hands of political power through which the conservative status quo could be maintained (Birtek \& Toprak 2011: 15). Between the 1950s and the 1980s, the public visibility of religion was indeed fostered by the redefinition of political Islam whose mobilization took place in line with the Turkish-Islamic synthesis and the restructuration of the welfare regime in light of right-wing neoliberal policies (White 2002; Eligür 2010; Toprak 2005; Tuğal 2009).

In this context, women's contribution to the Turkish Islamic movement was relevant: female sections of the Welfare Party were particularly active in the 1980s and 1990s (Arat 1998; White 2002b). The changing role of religion in the political sphere led to important implications regarding the role and mission of the Diyanet. Art. 136 of 1982 Constitution lists the protection of national sovereignty and integrity among the Diyanet tasks.

9 Such a recomposing of the religious realm and its relations with politics also involved the sections of society living abroad. Imams and religious officers were being sent to European countries from the early 1960s onwards (Dere 2008: 291-292) and the Diyanet intensified its activities between the late 1970s and the early 1980s. In 1978, the Turkish Councillorship for Religious Services [Din Hizmetleri Müşavirliği] was established in Germany together with the Attachés for Religious Services [Din Hizmetleri Ataşeliği] in Europe, US and Australia (Çitak 2010: 611-616). Between 1984 and 1985 both the Turkish-Islamic Union for Religious Affairs (DITIB) in Germany and the Diyanet's Department for International Relations [Dış İlişkiler Genel Müdürlüğü] were established. In the 1980s and 1990s, these measures were aimed to contain and control the activities of refugees and asylum seekers, particularly Kurds, having migrated from Turkey to Europe, together with members of outlawed political and religious organisations (Mencutek \& Baser 2017: 2).

10 The AKP's coming to power in 2002 should thus be contextualised in relation to a previous redefinition of the role of religion in Turkish domestic and foreign politics and policies. During the Ali Bardakoğlu presidency (2003-2010), the Diyanet undertook a reformulation of Islam as a social phenomenon: Bardakoğlu emphasised the "social function" of the Diyanet (Bardakoğlu 2008) and promoted new roles and visibility of religious officers extending beyond the mosque. Moreover, it was under the AKP government and the Ali Bardakoğlu appointment to the presidency of the Diyanet that women were included in the Diyanet bureaucracy (Maritato 2017; Tütüncü 2010). The number of women preachers, Qur'an teachers and vice-muftis increased during the 2000s and 2010s marking a redefinition of Diyanet policies towards women and the family (Maritato 2016).

11 Since the early 2000s, the Diyanet emerged as an international power ${ }^{6}$ via the export of imams from Turkey and the inauguration, in 2006, of the international program of theology to train students from abroad with Turkish roots as imams working in 
diaspora communities. These activities continued during Mehmet Görmez's presidency (2010-2017) and the current Ali Erbaş' one, and pertain also to women. The first group of women preachers arrived in Europe in the early 2000s and actively worked within the frame of Diyanet foundations' female sections [kadın kollarl]. Like their colleagues in Turkey, Diyanet officers in Europe are professionals (Maritato 2016). In 2017, the required conditions to apply for the national competition included: to be a Turkish citizen, to hold a degree in theology, to have been a Diyanet employee for the last three years, to pass a foreign language exam with at least 70 points/100; to be under 35 years old, to pass the Professional Proficiency Level Exam [Mesleki Bilgiler Seviye Tespit Sinavl, MBSTS] with at least 70 points/100. The exam consists of 80 questions pertaining to religion and information about the profession, knowledge about the services and range of activities provided by the Diyanet and general cultural knowledge (RG-26/10/2011-28096). In addition, applicants need to pass the Professional licence exam [Mesleki Ehliyet Sinavi], testing their erudition on the Qur'an and the precepts of Islam, and an interview with the Inter-ministerial Common Culture Commission [Bakanlıklar Arası Ortak Kültür Komisyonu Mülakatı] (Yerkazan 2017: 168-169). The selection criteria confirm that since the early 2000s, religious officers' competences in theology are tested together with history, language, culture and social aspects of the country of destination (Dere 2008: 293).

Diyanet officers abroad are employed for either a long period (up to 5 years) or a short one (up to 2 years) and their activities are under the supervision of Turkish Embassies and Consulates, where the religious attachés are charged with coordinating the activities carried out in the country's mosques. As I could confirm during my fieldwork, the Diyanet is providing imams and preachers with apartments for the duration of their stay. Such arrangements make them on par with diplomatic officials and provide religious actors with full legitimacy in the political field of the international arena ( Öztürk \& Sözeri 2018: 15).

As I observed through my fieldwork, both in Sweden and Austria, the Diyanet preachers tend to be in their thirties and with new-born or toddlers. The Diyanet appoints couples or families to the same city, particularly when both are Diyanet employees. In this way, they can simultaneously provide services for women and men of the same community. This is the case of the two women preachers operating in the Stockholm area. The preacher working in Tensta, Zeynep, is a 31 years old theology graduate. Her husband is also a preacher and works in the same mosque. They live with their two children in an apartment rented by the Diyanet in a district considered 'vulnerable' (The Local 21/06/2017) with a significant migrant population. The Turkish mosque is located in a two-floor apartment right in front of the metro station in Tenstagagen. Women meet on the first floor in a room equipped with kitchen, TV, tables and chairs, while the bigger prayer room is on the second floor. In a similar fashion, Fatma, the preacher working in Handen is 36 years old and lives with her husband - an employee at the Diyanet foundation - and their two children in an apartment adjacent to the mosque. Handen is located $20 \mathrm{~km}$ southeast of Stockholm; the area is quiet and surrounded by lakes and forests. The Diyanet mosque is close to a park and is the only mosque in town: three floors with separated kitchens, classrooms, and living rooms for men and women. Fatma is also a theology graduate who has previously worked as a preacher in Turkey to where she will return after five years in Sweden. In Vienna, Zehra, 42, is a preacher working in the Ertuğrul Gazi mosque located in the Brigittenau district. She is a theology graduate from Istanbul and will go back to Turkey after 
having spent 5 years in Austria. The mosque complex, which includes a cultural centre, apartments and a guesthouse, is built on the site of a former chocolate factory. Nimet, a 30 years old theology graduate is a preacher recently appointed to the Vienna ATIB head office in the Favoriten district. The five-floor building hosts a Turkish restaurant on the ground floor, a mosque on the first floor, one floor for offices charged with the institutions' main tasks: family guidance bureaus, cultural and social activities, religious services, administration of all the organisations affiliated to the union, funeral fund, pilgrimage to Mecca and Medina, one floor for a female dormitory, and another for a guesthouse and conference rooms.

\section{Teaching How to be a Muslim Woman in Europe}

14 To assess the significance of these relatively young and highly educated female religious officers sent from Turkey to reach Turkish (or of Turkish background) Muslim women living in Europe it is crucial to focus on the preaching sessions organised in Diyanet mosques. The main task that Diyanet female officers are given is indeed to provide religious knowledge (namely, Sunni Hanafi Islam). This occurs via Qur'an reading and exegesis sessions in which the preachers after reading a section of the Qur'an in Arabic give a short sermon. In their sermons, the preachers give pieces of advice and admonitions concerning personal behaviour and ways of conduct. In a session in Stockholm Tensta, Zeynep, the preacher, invited women to a daily practice of moderation and compliance:

We should always keep our faith strong; have faith and trust in the future, even when something negative is happening, because everything is possible for God. [...] We should use moderation in our life, do not exceed, and stay in the middle, in a like-minded and concord mood.?

In another session, after the reading, Zeynep explained the $12^{\text {th }}$ Sura of Yusuf (Joseph) qualifying it as: "the Sura that teaches people to be patient [sabir]. [...] We should be submissive [boyun eğme] to God, reading the Qur'an and praying every day". The preachers not only teach and enlighten women about religious knowledge; they are also spiritual guides, encouraging women to cultivate their faith. In a sermon during the Ramadan month, Fatma, the preacher working in the Handen mosque, elaborated on the Sura she read with a group of 40 women affirming that:

[...] The believer [mümin] behaves in the same way both in the mosque and outside.

[...] It is necessary to believe and to behave with justice, showing respect for the authority, and the executives [yöneticiler]. This is not just the President of the Republic but also our parents, our teachers, and so on. ${ }^{9}$

However, the preachers invite women not only to perform religious obligations and to behave according to Islamic principles, but also emphasise the qualities characterising an ideal devout woman, 'Muslim and modern' (Arat 1997; Sundal 2005; Kandiyoti 1997). Docility, obedience to authority and patience are among the recurring ones. Diyanet preachers provide a catechism combining religious and behavioural principles. The ideal pious and modern woman celebrated by the AKP (Arat 1998; Ayata \& Tütüncü 2008) is channelled to the diaspora communities through the Diyanet women preachers. While embodying a civil servant and an educated and economically independent woman, her pious behaviour challenges the ideal secular and modern woman symbol associated with the modern and westernised Turkish Republic (Kandiyoti \& Saktanber 2002; Kandiyoti 1988; Saktanber 1994; Durakbasa 1998; 
Bozdoğan \& Kasaba 1997; Göle 1996) as depicted by the early 1930s ruling elite. However, the 'secular and modern' woman was emancipated but not liberated (Kandiyoti 1987) as she remained the custodian of morality, emancipated by men and within a male-dominated environment in which she was expected to reproduce the traditional female role. In his book Nationalism and sexuality published in 1988, George Mosse analyses male and female national stereotypes confirming that "woman was idealised as the guardian of morality, exemplifying a virtue to be exerted in a passive way, protecting the continuity and the immutability of the nation, and its morality" (1988: 18). The idea of women as guardians of tradition and morality of the nation assumes even more relevance in a migratory context: being a Turkish Muslim woman in Europe means being able to perform religious practices, to live out religion every day in a non-Muslim public space (Jouili 2015; Aune, Sharma, \& Vincett 2008).

One of the ways that religious officers convey conservative messages to women is by presenting a model of Turkish Muslim women as antithetical to the one of 'secular Europe'. In this respect, the officers I met had a highly stereotyped vision of 'European women' and 'European families' as lacking morality, being far from religion and unable to take care of children and elderly people. This polarisation aimed at opposing two perceived homogenous and antithetic models of the East and West, religious and secular, has characterised the conservative rhetoric of the Turkish far right since the 1950s (Aytürk 2014; Bora 2018). Inspired by the Islamist ideologue Necip Fazıl Kısakürek the Büyük Doğu (Great East) ideology is an important reference for the AKP's intellectual and ruling elite (Taşkın 2017). The definition of the West as a threat to traditional values resonates in many sessions of the Diyanet preachers I attended. Preaching and behaving in a pious way in daily life is indeed designed as an antidote to any possible attempts to 'assimilate' to the 'European model'. The fear of 'assimilation' recurred in many conversations I had with female religious officers. In particular, it is relevant to mention their reference to a sense of discrimination due to the growing 'Islamophobia' that the Turkish Muslim community is victim of. However, I argue that the concept of Islamophobia is employed by Diyanet officers as a catalyst and unifying element aimed to mobilise and keep together communities ${ }^{10}$. A middle-aged woman attending a session in the Vienna ATIB head office mosque told me:

Here we always feel discriminated. When I go to the market, immediately people stare at me because of the headscarf. I feel judged for this. And I am afraid for my children, it is even more difficult for them: they grow up with different cultural models, and this may cause serious problems. ${ }^{11}$

18 Meeting with women attending the Diyanet sessions in Austria and in Sweden, I was told many times that despite living in the country for more than thirty or forty years, they were not able to speak the country's main language. Although this could be linked to a low level of education in the mother tongue, it shows the difficulty of eradicating practices of segregation and self-segregation. Moreover, attending the sermons in mosques, I could observe that the groups are composed of between 15 and 40 women during weekly meetings and 40-70 during religious feasts or the Ramadan month. It was always the same group of women living close to the mosque gathering together and thus fostering pre-existing networks and groups.

This aspect requires Diyanet's engagement with communities abroad to be addressed in all its complexity. On the one hand, Turkey renewed its interest for channeling religious conservative values to the diaspora as 'domestic abroad' (Varadarajan 2010), 
on the other hand, these practices are targeting only a segment of the diaspora, the one loyal to the government.

\section{Women's Sessions in Mosques: A Matter of Religious or Diaspora Policies?}

To fully assess the boost of Diyanet's grip on international affairs the matter should be included in a broader redefinition of the politics and policies toward the diaspora. A flourishing scholarship (Ünver 2013; Öktem 2014; Okyay 2015; Mencutek \& Baser 2017) has investigated the extent to which, how and when the diaspora has become an issue for the Turkish state and how and when it has been included as part of the government agenda. Institutions like the Turks Abroad and Kin Communities, a state agency linked to the Office of the Vice Presidency and established in March 2010, have been the output of a larger vision of the AKP's foreign policy. Outlined in Ahmet Davutoğlu's book Strategic Depth and shaped by the Milli Görüş (National Outlook), a nationalist Islamic movement considered one of the sources of ideological inspiration of the AKP, it consisted in a reformulation of an ethno-religious oriented and pan-Islamic foreign policy (Murinson 2006). This new foreign policy was implemented during the Davutoğlu's Ministry of Foreign Affairs mandate (2009-2014). Within that project, the Diyanet became a suitable tool for implementing selective diaspora policies representing the AKP vision of nationhood and its Sunni Muslim Turkish identity (Mencutek \& Baser 2017: 16).

During the 1980s, Turkey's politics and policies towards emigrants were reconfigured ex novo. The 1982 Constitution introduced one article (Art. 62) on emigrant affairs outlining the state's duties to ensure family unity, children's education, cultural need and social security of Turkish nationals working abroad, to reinforce their ties with the home country and facilitate their return (Aksel 2014).

political engagement with the communities abroad was concomitant to the already mentioned strengthening of the Diyanet's international role, the mosques in Europe became places where religious and cultural reproduction issues intersect such as the maintenance, modification or discarding of religious practices among the subsequent generations born and raised in post-migration settings (Vertovec 2004: 284). In this respect, women's pious behaviour is associated with the family and childcare. Attending the sessions organised by the Diyanet women preachers, I experienced how religious seminars are one of the loci where religious knowledge and moral values are transferred to diaspora families and young generations. The preachers invite women to bring their children to the mosque and to introduce them to the Qur'an classes from the age of 5 (Sözeri, Kosar-Altinyelken, \& Volman 2017). However, most of the activities are targeting teenagers who are perceived as the group that more often experiences conflicts with the family on matters related to cultural and religious practices. Fatma, one of the preachers working in the Vienna ATIB central mosque, explained to me why her role with teenagers is crucial: "I teach them not only religious knowledge but also practices. The mosque here is like a family, a place where we live and spend a lot of time."12

The professionalisation of religious officers and the regular appointing of religious officers to Europe contributes to the transformation of the mosques as a place of 
socialisation where those ties with the communities abroad that Valérie Amiraux defines as a "strategy of maintenance" (Amiraux 2002: 154-155) is performed. Women preachers' weekly schedule is indeed very tight. They organise Qur'an readings, sermons and exegesis sessions in the mosques every day except for one day off. The seminars are held in the morning or in the early afternoon, a few exceptions being those geared towards teenagers (held in the afternoons or on weekends) or working women (held in the late afternoons or in the evenings). In Austria, every Sunday all the preachers take turn to visit small towns nearby Vienna and other Austrian cities where they meet women and give sermons in local mosques. Besides routine religious services, training and guidance sessions in mosques, Diyanet officers regularly visit people at home, in hospitals and in prisons, and provide counselling services to Turkish Muslims suffering personal or family-related issues.

On different occasions, the preachers depicted their role as more complex than religious experts and spiritual guides. Describing her daily work, Zehra, the preacher of Vienna Ertuğrul mosque goes even further confirming: "Here [in Austria] you have to do all the tasks: you are at the same time a preacher, a Qur'an teacher, a psychologist [italics mine]." ${ }^{13}$ Religious counselling and moral support provided by the preacher is perceived as similar or alternative to consultations with psychologists. Hatice, the president of the Austrian Diyanet female section further elaborates:

Most of the women attending the sessions are elderly, often they are widows and spent all day at home alone. For them going to the mosque is a therapy, they socialise, share their problems, also many of them live in the vicinity of the mosque. 14

However, this aspect should be analysed in relation to the flourishing of Islamic psychology and its diffusion in Turkey (Skinner 2010; Rothman \& Coyle 2018). When I asked about how they deal with women facing serious personal or family problems, the preachers told me that, when their support is not enough to relieve the believers, they encourage the women to consult a psychologist. However, as Diyanet officers know that for many religious women, consulting a psychologist is not an easy task, they provide them with the number of 'friendly' psychologists who act in compliance with Islamic principles.

Moreover, Diyanet officers are engaged in manifold activities such as trips, picnics and cultural seminars (i.e. music or Turkish, German language courses). Hatice, president of the Vienna Diyanet's women section is convinced that:

For many women attending religious seminars and the activities organised by the ATIB, there are few occasions in which they can finally think about themselves, and this is very important. These moments are important because to socialise is important, not feeling alone at home is important. The alternative is to stay at home all day, to prepare food and to clean the house, doing always the same thing, every day. ${ }^{15}$

27 Against this backdrop, Diyanet female officers not only embody and propagate the model of a pious and modern woman complying with the AKP religious conservative ideology, they represent a pious and modern version of the Diyanet, an institution that since the early 2000s has restructured its media channels (TV, website, radio, YouTube channels, social networks) in order to reach young people, women, and the diaspora. The Diyanet officers I met were all conscious of and emphasising the importance of the moral support and religious service they provide to the communities abroad. This 
effort has contributed to a redefinition of the religious officers' role in society, claiming spaces and recognition in matters related to family, education, and healthcare.

Through these multifaceted socialisation activities and the redefinition of religious counselling abroad, Diyanet mosques in Europe reflect how a strong focus on diaspora communities is implemented through religion. However, although Diyanet officers propagate a unifying and standardised discourse, they face potential heterogeneous audiences in terms of ethnics, religious interpretation, social and cultural capital. Ethnic difference, as in the case of Kurdish communities in Sweden and Austria ${ }^{16}$, is easily overcome when religious conservative conduct and a loyalty to the government are displayed. The same issue concerns the Fethullah Gülen movement abroad. After the falling apart of the alliance with the AKP in 2013 and accusations of having orchestrated the 2016 attempted coup, the Gülen movement is now more isolated and hidden. In some European countries, cases of imams accused of taking part in intelligence gathering and spying activities within Turkish communities (Öztürk 04/04/2017) have made the headlines, fueling polarisation within the diaspora. This reinforces the conclusions of many recent studies on the Turkish government's diaspora policies as being exclusively implemented for pro-government religious conservative Sunni Muslim Turks and that the Diyanet acts as an implementer of the AKP government's ideology (Öztürk 2016). However, besides the passive role of the institution and its employees acting as megaphones for the ruling elite's discourse, the Diyanet has recently undertaken a profound transformation in which religious officers are in the foreground.

\section{Concluding remarks}

The paper investigates Diyanet female officers' activities in Austria and Sweden within the broader context of its activities in Europe. It emphasises how in the past two decades the status, the competences and the visibility of female religious officers have profoundly evolved. Charged with providing religious education to women, the role of female religious officers within Turkish communities in Europe is the result of two concomitant factors: on the one hand is the AKP strategy to employ the Diyanet as a tool to reach the widest possible audience and propagate the religious conservative ideology abroad. On the other hand, it has resulted from the Diyanet's increasing agency leading to a professionalisation of religious officers whose role and competences have evolved since the early 2000s. Religious officers abroad enjoy a status that might be defined as a sort of 'religious diplomats' (Öztürk \& Sözeri 2018): appointed for a maximum of five years ${ }^{17}$, the Diyanet provides them with accommodation and coordinates their activities through the religious attachés employed in Turkish embassies and consulates. Such an international mission is particularly effective in the case of the religious sessions as well as visits and socialising activities organised for women. Although replicating forms of activism and group cohesion attributable to the tradition of female Islamist mobilisation (White 2002b; Arat 1999), rapid conclusions should be avoided. Diyanet female officers in Europe are civil servants; while at the service of the diaspora, they represent the establishment and embody a Janus-faced policy and represent a bureaucratic apparatus, with a 'human face'. 
Based on observations of the activities organised by female officers in Diyanet mosques in Stockholm and Vienna, the study highlights women's contribution in expanding Diyanet's international mission. While fostering religious knowledge, they also provide moral guidance and support to women. The seminars in mosques are indeed also places of socialisation and 'therapy' sessions for those women experiencing segregation due to language, cultural, economic or social barriers. To fully assess the significance of women's involvement in Diyanet branches abroad it is thus necessary to combine the institution's 'passive' role as an instrument or a tool which the ruling elite employ to propagate religious conservative discourse to the diaspora with a more 'active' role that has recently seen Diyanet officers gaining the foothold beyond the mosques as religious experts whose competences have broadly expanded. Against this background, further research should consider that Diyanet's commitment for Turkish Muslim women and families living abroad affects only the more conservative segment of the Turkish diaspora. In this regard, the establishment of new niches of supporters of the AKP's religious nationalist ideology creates networks that might be mobilised for political or electoral purposes. This aspect contributes to studies on the prominent role of religious actors in the implementation of both AKP foreign policy (Öztürk \& Sözeri 2018) and its policies toward the diaspora (Öktem 2014; Mencutek \& Baser 2017).

\section{BIBLIOGRAPHY}

Akgönül, Samim (2005). «Islam turc, islams de Turquie : acteurs et réseaux en Europe. » Politique étrangère 1, p. 35-47. DOI: 10.3406/polit.2005.1084.

Aksel, Damla B. (2014). “Kins, Distant Workers, Diasporas: Constructing Turkey's Transnational Members Abroad.” Turkish Studies 15(2), p. 195-219. DOI: 10.1080/14683849.2014.926233.

Allievi, Stefano \& Nielsen, Jørgen S. (2003). Muslim Networks and Transnational Communities in and Across Europe. Leiden, Brill.

Amiraux, Valérie (2002). “Turkish Political Islam and Europe: Story of an Opportunistic Intimacy." In Jørgen Nielsen \& Stefano Allievi (eds.), Muslim Networks and Transnational Communities in and across Europe. Leiden, Brill, p. 146-69.

Arat, Yeşim (1999). “Political Islam in Turkey and Women's Organizations.” Istanbul, TESEV Publications.

Arat, Yeşim (1998). “Feminists, Islamists, and Political Change in Turkey.” Political Psychology 19(1), p. 117-31. DOI: 10.1111/0162-895X.00095.

Arat, Yeşim (1997). “The Project of Modernity and Women in Turkey.” In Sibel Bozdoğan and Reşat Kasaba (eds.), The Quest for the Islamic Self within the Context of Modernity. Washington, University of Washington Press, p. 95-112.

Aune, Kristin; Sharma, Sonya \& Vincett, Giselle (2008). Women and Religion in the West: Challenging Secularization. Farnham, Ashgate. 
Auyero, Javier (2006). "Introductory Note to Politics under the Microscope: Special Issue on Political Ethnography I." Qualitative Sociology 29(3), p. 257-259. DOI: 10.1007/s11133-006-9028-7.

Avci, Gamze (2005). “Religion, Transnationalism and Turks in Europe.” Turkish Studies 6(2), p. 201-13. DOI: 10.1080/14683840500119536.

Ayata, Ayşe Guneş \& Tütüncü, Fatma (2008). "Party Politics of the AKP (2002-2007) and the Predicaments of Women at the Intersection of the Westernist, Islamist and Feminist Discourses in Turkey." British Journal of Middle Eastern Studies 35(3), p. 363-384. DOI:

10.1080/13530190802525130.

Aydın, Yaşar (2014). “The New Turkish Diaspora Policy.” Stiftung Wissenschaft Und Politik German Institute for International and Security Affairs. URL: https://www.swp-berlin.org/ fileadmin/contents/products/research_papers/2014_RP10_adn.pdf.

Aytürk, Ilker (2014). “Nationalism and Islam in Cold War Turkey, 1944-69.” Middle Eastern Studies 50(5), p. 693-719. DOI: 10.1080/00263206.2014.911177.

Bardakoğlu, Ali (2008). "The Structure, Mission and Social Function of the Presidency of Religious Affairs (PRA).” The Muslim World 98(2-3), p. 173-181. DOI: 10.1111/j.1478-1913.2008.00217.x.

Bedirhaber (31/01/2017). “Diyanet 102 ülkede hizmet veriyor”, Bedirhaber. http:// bedirhaber.com/haber/diyanet-102-ulkede-hizmet-veriyor-48108.html.

Birtek, Faruk \& Toprak, Binnaz (2011). “The Conflictual Agendas of Neo-Liberal Reconstruction and the Rise of Islamic Politics in Turkey: The Hazard of Rewriting Modernity." In Faruk Birtek \& Binnaz Toprak (eds.), The Post-Modern Abyss and the New Politics of Islam: Assabiyah Revisited, Essays in Honor of Şerif Mardin. Istanbul, Bilgi University Press, p. 13-35.

Bora, Tanıl (2018). Türk Sağının Üç Hali (The Three States of the Turkish Right), Istanbul, Iletişim.

Bozdoğan, Sibel \& Kasaba, Reşat (1997). Rethinking Modernity and National Identity in Turkey.

Washington, University of Washington Press.

Bruce, Benjamin (2012). «Les imams "exportés" de la Diyanet en France : enjeu de politique étrangère, enjeu de politique intérieure ", Cahiers de l'OBTIC 2, p. 15-20. URL: http:// spire.sciencespo.fr/hdl:/2441/3qe72d0aov9itbp22uik8ntqmu/resources/pages-decahiersobtic-2.pdf.

Çitak, Zana (2018). “National Conceptions, Transnational Solidarities: Turkey, Islam and Europe.” Global Networks 18(3), p. 377-398. DOI: 10.1111/glob.12184.

Çitak, Zana (2010). “Between 'Turkish Islam' and 'French Islam': The Role of the Diyanet in the Conseil Français du Culte Musulman.” Journal of Ethnic and Migration Studies 36(4), p. 619-634. DOI: 10.1080/13691830903421797.

Davison, Andrew (2003). “Turkey, a 'Secular' State?: The Challenge of Description.” The South Atlantic Quarterly 102(2-3), p. 333-350. URL: https://muse.jhu.edu/article/43708.

Demir, Zekiye (2010). Almanya'da Yaşayan Türk Kadınları Durumları, Sorunları, Din ve Diyanet Algıları. Ankara, Diyanet İşleri Başkanlığı Yayınları.

Dere, Ali (2008). "The PRA of Turkey: The Emergence, Evolution and Perception of Its Religious Services Outside of Turkey.” The Muslim World 98(2-3), p. 291-301. DOI: 10.1111/j.

1478-1913.2008.00227.x. 
Diyanet İşleri Başkanlığı (2018). “2017 Faaliyet Raporu.” Ankara, Diyanet İşleri Başkanlığı. URL: http://www2.diyanet.gov.tr/StratejiGelistirme/Faaliyet/ 2017\%20Y\%C4\%B11\%C4\%B1\%20Faaliyet\%20Raporu.pdf.

Diyanet İşleri Başkanlığı (2011). Hizmetler ve Projeler 2003-2010. 818. Ankara, Diyanet İşleri Başkanlığı.

Dubois, Vincent (2009). "Towards a Critical Policy Ethnography: Lessons from Fieldwork on Welfare Control in France." Critical Policy Studies 3(2), p. 221-239. DOI: $10.1080 / 19460170903385684$.

Durakbasa, Ayse (1998). “Kemalism As Identity Politics in Turkey.” In Zehra Arat (eds.), Deconstructing Images of Turkish Women. New York, St. Martin Press, p. 139-155.

Eligür, Banu (2010). The Mobilization of Political Islam in Turkey. Cambridge, Cambridge University Press.

Göle, Nilüfer (1996). The Forbidden Modern: Civilization and Veiling. Ann Arbor, University of Michigan Press.

Gözaydın, İstar B. (2014). "Management of Religion in Turkey: The Diyanet and Beyond.” In Özgür Heval çınar \& Mine Yildirim (eds.) Freedom of Religion and Belief in Turkey. Cambridge, Cambridge Scholars Publishing, p. 10-36.

Gözaydın, İstar B. (2008). “Diyanet and Politics.” The Muslim World 98(2-3), p. 216-227. DOI: 10.1111/j.1478-1913.2008.00220.x.

Hürriyet (18/11/2017). “Türkiye tarihinde bir ilk”, Hürriyet. http://www.hurriyet.com.tr/ gundem/turkiye-tarihinde-bir-ilk-40649554.

Jouili, Jeanette S. (2015). Pious Practice and Secular Constraints: Women in the Islamic Revival in Europe. Redwood City, Stanford University Press.

Kandiyoti, Deniz (1997). "Gendering the Modern. On Missing Dimensions in the Study of Turkish Modernity." In Sibel Bozdoğan \& Reșat Kasaba (eds.), The Quest for the Islamic Self within the Context of Modernity. Washington, University of Washington Press, p. 113-132.

Kandiyoti, Deniz (1988). "Bargaining with Patriarchy." Gender \& Society 2(3), p. 274-290. DOI: 10.1177\%2F089124388002003004.

Kandiyoti, Deniz (1987). "Emancipated but Unliberated? Reflections on the Turkish Case." Feminist Studies 13(2), p. 317-338. DOI: 10.2307/3177804.

Kandiyoti, Deniz, and Saktanber, Ayşe (2002). Fragments of Culture: The Everyday of Modern Turkey. New Brunswick, N.J., Rutgers University Press.

Kocamaner, Hikmet (2017). "Strengthening the Family through Television: Islamic Broadcasting, Secularism, and the Politics of Responsibility in Turkey." Anthropological Quarterly 90(3), p. 675714. DOI: $10.1353 /$ anq.2017.0040.

Levin, Paul T. \& Baser, Bahar (2017). Migration from Turkey to Sweden: Integration, Belonging and Transnational Community. London, New York: I.B. Tauris.

Lord, Ceren (2018). “The Story Behind the Rise of Turkey's Ulema.” Middle East Research and Information Project (MERIP). URL: http://merip.org/mero/mero020418.

Maritato, Chiara (2017). “To Make Mosques a Place for Women. Female Religious Engagement within the Turkish Presidency of Religious Affairs." In Meltem Ersoy \& Esra Ozyurek (eds.) 
Contemporary Turkey at a Glance II: Turkey Transformed? Power, History, Culture. New York, Springer, p. 39-52. DOI: 10.1007/978-3-658-16021-0_3.

Maritato, Chiara (2016). "Reassessing Women, Religion and the Turkish Secular State in the Light of the Professionalisation of Female Preachers (Vaizeler) in Istanbul.” Religion, State and Society 44(3), p. 258-275. DOI: 10.1080/09637494.2016.1204168.

Maritato, Chiara (2015). “Performing Irşad: Female Preachers' (Vaizeler's) Religious Assistance Within the Framework of the Turkish State." Turkish Studies 16(3), p. 433-447. DOI: 10.1080/14683849.2015.1056520.

Mencutek, Zeynep Sahin \& Baser, Bahar (2017). “Mobilizing Diasporas: Insights from Turkey's Attempts to Reach Turkish Citizens Abroad." Journal of Balkan and Near Eastern Studies 20(1), p. 86105. DOI: 10.1080/19448953.2017.1375269.

Turkish Ministry of Foreign Affairs (n.d.). "Yurtdışında Yaşayan Türk Vatandaşları" (Turkish citizens residing abroad), MFA. http://www.mfa.gov.tr/yurtdisinda-yasayan-turkler_.tr.mfa.

Mosse, George L. (1988). Nationalism and Sexuality: Middle-Class Morality and Sexual Norms in Modern Europe, Reprint ed. Madison, University of Wisconsin Press.

Murinson, Alexander (2006). "The Strategic Depth Doctrine of Turkish Foreign Policy.” Middle Eastern Studies 42(6), p. 945-964. DOI: 10.1080/00263200600923526.

Nielsen, Jørgen; Akgönül, Samim; Alibašić, Ahmet \& Racius, Egdunas (2014). Yearbook of Muslims in Europe, Leiden, Brill.

Öktem, Kerem (2014). “Turkey's New Diaspora Policy: The Challenge of Inclusivity, Outreach and Capacity.” Istanbul, IPC. URL: http://ipc.sabanciuniv.edu/wp-content/uploads/ 2014/08/14627_Kerem\%C3\%96ktenWEB.18.08.pdf.

Öktem, Kerem (2012). “Global Diyanet and Multiple Networks: Turkey’s New Presence in the Balkans." Journal of Muslims in Europe 1(1), p. 27-58. DOI: 10.1163/221179512X644042.

Okyay, Asli Selin (2015). “Diaspora-Making as a State-Led Project : Turkey’s Expansive Diaspora Strategy and Its Implications for Emigrant and Kin Populations.” EUI PhD theses; Department of Political and Social Sciences.

Ozgur, Iren (2012). Islamic Schools in Modern Turkey: Faith, Politics, and Education. Cambridge, Cambridge University Press.

Öztürk, Ahmet Erdi (04/04/201). “Does Turkey Use ‘Spying Imams’ To Assert Its Powers Abroad?”, The Conversation. https://www.huffingtonpost.com/entry/does-turkey-use-spying-imams-toassert-its-powers_us_58e3906ce4b09deecf0e1a1f?ec_carp=5450175769493395800.

Öztürk, Ahmet Erdi (2016). “Turkey's Diyanet under AKP Rule: From Protector to Imposer of State Ideology?" Southeast European and Black Sea Studies 16(4), p. 619-635. DOI: 10.1080/14683857.2016.1233663.

Öztürk, Ahmet Erdi \& Sözeri, Semiha (2018). "Diyanet as a Turkish Foreign Policy Tool: Evidence from the Netherlands and Bulgaria." Politics and Religion 11(3), p. 1-25. DOI: 10.1017/ S175504831700075X.

Resmi Gazete (RG-26/10/2011-28096). “Diyanet İşleri Başkanlığı Sınav Yönetmeliği” (Regulation on Examination of the Directorate of Religious Affairs), Resmi Gazete. http://www.mevzuat.gov.tr/ Metin.Aspx?MevzuatKod=7.5.15433\&MevzuatIliski=0\&sourceXmlSearch. 
Rothman, Abdallah \& Coyle, Adrian (2018). “Toward a Framework for Islamic Psychology and Psychotherapy: An Islamic Model of the Soul." Journal of Religion and Health 57(5), p. 1731-1744. DOI: $10.1007 /$ s10943-018-0651-x.

Saktanber, Ayşe (1994). "Becoming The 'Other' as a Muslim in Turkey: Turkish Women vs. Islamist Women.” New Perspectives on Turkey 11, p. 99-134. DOI: 10.1017/S089663460000100X.

Schatz, Edward (2013). Political Ethnography: What Immersion Contributes to the Study of Power. Chicago, University of Chicago Press.

Şenay, Banu (2012). “Trans-Kemalism: The Politics of the Turkish State in the Diaspora.” Ethnic and Racial Studies 35(9), p. 1615-1633. DOI: 10.1080/01419870.2011.595807.

Shore, Cris, and Wright, Susan (1997). Anthropology of Policy: Perspectives on Governance and Power. New York, Milton Park, Taylor \& Francis.

Skinner, Rasjid (2010). “An Islamic Approach to Psychology and Mental Health.” Mental Health, Religion \& Culture 13(6), p. 547-551. DOI: 10.1080/13674676.2010.488441.

Sözeri, Semiha; Kosar-Altinyelken, Hülya \& Volman, Monique (2017). "Mapping Discourses on Mosque Education in the Netherlands: A Content Analysis of the Dutch Press, 2010-2016." Discourse: Studies in the Cultural Politics of Education, p. 1-14. DOI: 10.1080/01596306.2017.1316705. Sundal, Fatma (2005). "Invisible Women Visible Islam: Engendering Everyday Lives Of Educated Islamist Women In Turkey.” Anadolu University Journal of Social Sciences 5(1), p. 109-130. URI: http://hdl.handle.net/11421/459.

Sunier, Thijl \& Landman, Nico (2014). Transnational Turkish Islam. London, Palgrave McMillan. Sunier, Thijl; Landman, Nico; Van der Linden, Heleen; Bilgili, Nazlı \& Bilgili, Alper (2011). "The Turkish Directorate for Religious Affairs in a Changing Environment." VU University Amsterdam and Utrecht University. URL: http://www.fsw.vu.nl/nl/Images/

Diyanet\%20report\%202011_tcm30-421402.pdf.

Taşkın, Yüksel (2017). AKP Devri (The AKP Era), Istanbul, Iletişim.

The Local (21/06/2017). "So... are they no-go zones? What you need to know about Sweden's vulnerable areas", The Local. https://www.thelocal.se/20170621/no-go-zones-what-you-need-toknow-about-swedens-vulnerable-aeas.

Toprak, Binnaz (2005). “Islam and Democracy in Turkey.” Turkish Studies 6(2), p. 167-186. DOI: https://doi.org/10.1080/14683840500119494.

Tuğal, Cihan (2009). Passive Revolution: Absorbing the Islamic Challenge to Capitalism. Redwood City, Stanford University Press.

Tütüncü, Fatma (2010). “The Women Preachers of the Secular State: The Politics of Preaching at the Intersection of Gender, Ethnicity and Sovereignty in Turkey." Middle Eastern Studies 46(4), p. 595-614. DOI: 10.1080/00263200903189833.

Ünver, Can (2013). "Changing Diaspora Politics of Turkey and Public Diplomacy.” Turkish Policy Quarterly 1(12), p. 182-189. URL: http://turkishpolicy.com/Files/ArticlePDF/changing-diasporapolitics-of-turkey-and-public-diplomacy-spring-2013-en.pdf.

Varadarajan, Latha (2010). The Domestic Abroad: Diasporas in International Relations. Oxford, Oxford University Press. 
Vertovec, Steven (2004). "Religion and Diaspora." In Peter Antes; Armin W. Geertz \& Randi Ruth Warne (eds.), New Approaches to the Study of Religion. Volume 2. Textual, Comparative, Sociological, and Cognitive Approaches. Berlin, de Gruyter, p. 275-304.

Wedel, Janine R.; Shore, Cris; Feldman, Gregory \& Lathrop, Stacy (2005). “Toward an Anthropology of Public Policy." The Annals of the American Academy of Political and Social Science 600, p. 30-51. DOI: $10.1177 \% 2 F 0002716205276734$.

White, Jenny B (2002). Islamist Mobilization in Turkey: A Study in Vernacular Politics. Seattle, University of Washington Press.

White, Jenny B (2002b). “The Islamist Paradox.” In Deniz Kandiyoti \& Ayşe Saktanber (eds.), Fragments of Culture. London, I.B.Tauris, p. 191-217.

Yanow, Dvora (1996). How Does a Policy Mean?: Interpreting Policy and Organizational Actions. Washington, Georgetown University Press.

Yazıc1, Berna (2012). "The Return to the Family: Welfare, State, and Politics of the Family in Turkey.” Anthropological Quarterly 85(1), p. 103-140. DOI: 10.1353/anq.2012.0013.

Yerkazan, Hasan (2017). "Diyanet İşleri Başkanlığınca Yurt Dışında Görevlendirilen Din Görevlilerinin Hadîs Bilgi Ve Kültürü Üzerine Bir Araștırma.” (A Study on the Knowledge and Culture of Hadith of Religious Officers assigned by the Presidency of Religious Affairs), AUID 9, p. 165-197. URL: http://dergipark.gov.tr/download/article-file/378475.

Yükleyen, Ahmet (2011). Localizing Islam in Europe: Turkish Islamic Communities in Germany and the Netherlands. Syracuse NY, Syracuse University Press.

Yurdakul, Gökçe, and Yükleyen, Ahmet (2009). “Islam, Conflict, and Integration: Turkish Religious Associations in Germany.” Turkish Studies 10(2), p. 217-231. DOI:

10.1080/14683840902864010.

\section{NOTES}

1. On 18 November 2017, Huriye Martı has been the first woman appointed to the Diyanet's vicePresidency (Hürriyet 18/11/2017).

2. The Austrian Turkish Islamic Union [Avusturya Türkiye İslam Birliği, ATIB] has been founded in 1990 and is the Austria's largest Muslim organization, an umbrella which currently count a total of 65 associations of which 8 in Vienna where there are six Diyanet mosques. I attended sessions organised in Ertuğrul Gazi mosque located in the $20^{\text {th }}$ district, Brigittenau and in the ATIB central mosque is located in Vienna, in the $10^{\text {th }}$ district called Favoriten.

3. The Swedish Diyanet Foundation [İsveç Diyanet Vakfi] was established in 1984 and is located in Huddinge, a municipality in Stockholm urban area. The foundation is currently responsible for eight mosques in Sweden: Fittja, Göteborg, Handen, Rinkeby, Tensta, Fleminsberg, Malmo, Jonkoping, all registered as non-profit cultural associations. In this paper, I will mostly refer to two districts where I conducted the ethnographic observation: Tensta and Handen.

4. Please see: https://www.statistik.at/web_en/statistics/PeopleSociety/population/ population_change_by_demographic_characteristics/population_with_foreign_background/ index.html.

5. Preachers and religious officers' names in the article do not correspond to reality.

6. In 2017, the Diyanet provides religious services in 102 countries (Bedirhaber 31/01/2017).

7. Stockholm Tensta, Diyanet mosque, 10 June 2017.

8. Stockholm Tensta, Diyanet mosque, 6 June 2017. 
9. Handen, Diyanet mosque, 8 June 2017.

10. This aspect deserves further research particularly considering the Diyanet involvement in discussing Islamophobia also on its official media channels. TRT Diyanet hosts a TV program called Islamofobi Endustrisi (Islamophoby Industry) For more information, please see: https:// www.diyanet.tv/islamofobi-endustrisi.

11. Vienna ATIB head office mosque, 30 November 2017.

12. Vienna ATIB head office mosque, 30 November 2017.

13. Vienna Diyanet Ertuğrul mosque (Brigittenau), 29 November 2017.

14. Vienna ATIB head office mosque, 29 November 2017.

15. Vienna ATIB head office mosque (Favoriten), 29 November 2017.

16. Both Austrian and Swedish diaspora communities have members originating from Kulu, a district of Konya province in Anatolia. In particular, the Swedish migration from Kulu dated 1965. In 2015, Diyanet TV [TRT Diyanet] produced a 22-episode documentary called Stockholm Treni about the Kulu Migration. For more info please see (Levin \& Baser 2017).

17. The period abroad lasts for a maximum of five years and can be fulfilled only twice. However, the second appointment should occur after two years of service in Turkey.

\section{ABSTRACTS}

Since the early 2000s, an increasing number of female religious officers have been employed by the Presidency of Religious Affairs (Diyanet) and regularly sent to European countries. Tasked with providing religious knowledge and moral support to women, their engagement epitomises Diyanet's contribution to the AKP government's wide-ranging international mission aimed at reaching Turkish citizens living abroad. To assess the significance of the activities organised for Turkish women migrated to Europe, the paper aims to answer the following questions: How does the 'export' of Diyanet female religious officers fit into Diyanet's grip on international affairs? What is women's contribution in this respect? And how do the activities of Diyanet women preachers in Europe reflect Turkey's current diaspora policies? Drawing on ethnographic observation and interviews with the Diyanet female officers in Vienna and Stockholm mosques, this contribution concludes that Diyanet officers' role and agency abroad is the result of a combination of two concomitant and interconnected factors The paper argues that female religious officers' activities abroad should be included in a multifaceted reconfiguration of: i) the Diyanet's long lasting international mission; ii) the role women play in the diffusion of religious knowledge and morality; iii) the boundaries between Turkey's religious and diaspora policies.

INDEX

Keywords: Women, Muslim, Europe, Turkey, Diyanet 


\section{AUTHOR}

\section{CHIARA MARITATO}

Post-doc Assistant Professor

Center for Southeast European Studies (CSEES)

University of Graz

chiara.maritato@uni-graz.at 